\title{
Programming of skilled football players training process in the second cycle of specially created training during the year
}

\author{
Kostiukevich V.M. ${ }^{1}$, Stasiuk V.A. ${ }^{2}$, Shchepotina N.Yu. ${ }^{1}$, Dyachenko A.A. ${ }^{1}$ \\ ${ }^{1}$ Vinnytsya State Pedagogical University Named After Mikhaylo Kotsubinskiy, Ukraine \\ ${ }^{2}$ Kamianets-Podilskyi Ivan Ohienko National University, Ukraine
}

\begin{abstract}
Purpose:

of the research is to prove experimentally the skilled football players training process in the annual macrocycle on the basis of programming.

Material: $\quad$ the skilled football players participated in a research ( $n=20$, age 18-23 years). Control provided use of the following tests: 30 m run; shuttle run $7 \times 50 \mathrm{~m}$; long jump from the spot; Cooper's test.

Results: $\quad$ programs of training microcycles were developed. In each program such components of the training were considered: value and orientation of loads; means (non-specific and specific); modes of coordination complexity of exercises performance; training time; time for renewal of competition form, theoretical and psychological preparation; load coefficient value; intensity of training load coefficient.

Conclusions: Programming of training process has to be carried out on the basis of systemically structural approach: the development of programs of less structural formations has to be subordinated to the main structural formations. The structure of microcycles includes programs of trainings. Programs of stages consist of a series of training microcycles programs. The program of a training cycle unites all structural formations.

Keywords: training process, football players, planning, programming, macrocycle.
\end{abstract}

\section{Introduction}

The present state of football development demands search of the most optimum ways of the organization of athletes training process at different stages of the annual training cycle.

Creation of training process has to be carried out on the basis of conceptual approach which provides:

- system approach to creation of structural formations of training process (set of exercises and complexes, trainings, micro and mesocycles, stages, periods, macrocycles);

- phasicity of development of athletes' competition form; the highest level of it has to be on the period of the main competitions: planning of athletes' training process has to be carried out on the basis of competitions' calendar;

- accounting of sport development tendencies and created system of athletes training at the stages of longterm training;

- character and features of competitive activity in sport: intensity of sport fight, loss of power during the competition.

Training process of athletes is carried out on the basis of planning: long-term, perspective, annual, set of stages. The planning is previously planned operations procedure necessary for achievement of desired goal. Planning provides quantitative parameters of athletes' training during the certain period of their preparation. There is a question: as far as planning is an effective component in the general structure of administrative decisions?

Planning allows to distribute parameters of athletes' training during a certain cycle. Planning also allows to determine the content of structural formations of training process (training occupations, micro and mesocycles). But it is difficult to consider process of athletes' training in dynamics on the basis of planning, in interrelation with

\footnotetext{
(C) Kostiukevich V.M., Stasiuk V.A., Shchepotina N.Yu.,

Dyachenko A.A., 2017
}

doi:10.15561/20755279.2017.0602 the different parties of preparation. The main thing is that planning doesn't allow to define purposeful influence on training effects' formation: urgent, delay, cumulative. Programming of training process can be used for this purpose in structure of administrative influences.

Programming is an improvement of training process content according to the target tasks of athletes' training and the specific principles which define rational forms of training loads organization within a certain training stage [2]. Programming began to be used in the course of study in the 20th years of the last century by the American scientists: B.F. Skinner has developed the linear program of study; N. Krauder has developed the branched program of study.

S.V. Malynovskyi was one of the first scientists who introduced programmable study in physical training. The author has developed universal programs of training material study [14]. The basic methodical principles of programming and organization of skilled athletes training process have been created by Yu.V. Verkhoshanskyi [2].

In the system of athletes' training the fundamental problem is provement of programming theoretical and methodical bases at the present stage of sport' development. This problem is studied at the works of native $[16,19]$ and foreign $[22,23]$ scientists. Certain aspects of implementation of basic provisions of programming in team game sports were considered by many experts: development of effective programs of athletes' training in field hockey [12], football [13], volleyball [20].

Results of numerous researches of athletes' training problems in team game sports demonstrate prospects of individual programs application. In particular, use of the factorial analysis allows to find the most developed skills of players. It is necessary to develop the backward skills at creation of individual training process [9]. Experts note the necessity of individual approach to planning of volumes and intensity of achievement training loads. Its adaptation is significantly limited by individual capability of athletes [31]. 
Development and implementation of training programs of selective orientation are characteristics features of sport games. Efficiency of speed and strength skills improvement is proved as main for the achievement of good results in basketball [3]. It is recommended to use loads of strength [25, 34], anaerobic [32] and aerobic [36] orientations for rational training of football players. Training programs for the different categories of readiness is applied in practice of athletes' training of team game sports $[12,21]$ : technical and tactical $[7,29]$, physical [33, 34]. In the system of a sports training deserve attention: the flowchart of programming of skilled athletes' training [10]; programs of pedagogical $[15,28]$ and medicobiological [24, 35] control.

The research of programming problem is relevant in practice of football players' training of different qualification. S. Yu. Tyilenkov [17] has developed programs of football players training of high qualification at the different stages of annual training cycle. M.A. Bukuyev [1] studied technique of landmark programming of training loads. V.M. Shamardinim [18] investigated the management technology of long-term training system of the football teams of the top qualification. The author proved two versions of training programs for football team which participates in Eurocups.

Researches of foreign scientists were devoted to the problem of programming of skilled football players training process. The famous Dutch trainer R. Michels [30] developed the basic tactics principles of total football on the basis of programming. Programs of the differentiated approach in the training process of football players were investigated by H. Kormelink, T. Seeverens [26, 27]. Famous Canadian expert T. O. Bompa revealed the system of a complex training on the basis of programming [22].

The carried out analysis of references allows to claim that the problem of training process' creation of athletes on the basis of programming is relevant and perspective. At the same time it should be noted that development and provement of methodical approaches concerning creation of training process of the skilled football players on the basis of programming within an annual macrocycle are almost unresolved.

Hypothesis. It is provided that creation of skilled football players training process on the basis of programming will increase its efficiency.

The purpose of the research is to prove experimentally the skilled football players training process in annual macrocycle on the basis of programming.

\section{Material and methods.}

The qualified football players of Kamyanets-Podilsky Ivan Ohienko National University participated in a research ( $n=20$, age 18-23 years). All participants gave a written approval of participation in this experiment.

Organization of $\boldsymbol{a}$ research. The research was conducted within two years. In the course of pedagogical observation over training activities of football players realized timing of trainings (fixing of character and time of exercises). The heart rate (HR) was simultaneous registered. The monitor of heart rate Polar Rs800cx was used.

The analysis of output data allowed to define:

1) pedagogical directivity of means:

- nonspecific exercises (without balls) or specific (with balls), general training, special training, preliminary or competitive exercises, speed, speed and strength preparedness $[12,16]$;

- mode of coordination complexity. The technical and tactical actions (TTA) belonged to the first mode of coordination complexity (MCC) which executed on the spot or on convenient traverse speed. TTA executed in movement with restriction in space and time belonged to the second MCC. TTA executed in the conditions of the active counteraction from the rival [12, 28] belonged to the third MCC;

2) physiologic directivity of loads: loads of an aerobic, mixed aerobic and anaerobic, anaerobic alactic or anaerobic glycolytic orientation $[4,16,35]$;

3 ) load value coefficient was defined according to the formula $[6,12]$ :

$$
\text { LMC }=\sum_{i=1}^{n} t_{i} \cdot I_{i},
$$

where: $L M C$ - load value coefficient; $n$ - number of exercises; $t_{i}$ - duration of separate exercise; $I_{i}$ - intensity of exercise depending on $\operatorname{HBR}[6,12]$ : intensity of exercise with HBR $114 \mathrm{bpm}^{-1}$ is evaluated in 1 point; $120 \mathrm{bpm}^{-1}-2$ points; $126 \mathrm{bpm}^{-1}-3$ points; $132 \mathrm{bpm}^{-1}-4$ points; 138 bpm $^{-1}-5$ points; 144 bpm $^{-1}-6$ points; 150 bpm $^{-1}-7$ points; $156 \mathrm{bpm}^{-1}-8$ points; $162 \mathrm{bpm}^{-1}-10$ points; 168 bpm $^{-1}-12$ points; 174 bpm $^{-1}-14$ points; 180 bpm $^{-1}-17$ points; $186 \mathrm{bpm}^{-1}-21$ points; $192 \mathrm{bpm}^{-1}-25$ points; 198 $\mathrm{bpm}^{-1}-33$ points;

4) training load intensity coefficient was defined according to the formula $[12,28]$ :

$$
\mathrm{IC}=\frac{\mathrm{LMC}}{\mathrm{T}},
$$

where: $I C$ - training load intensity coefficient; $T$ - time of training.

Data on the each training have been written in the scheme of a microcycle [12]. As a result of synthesis of the obtained data it has been defined: volume, value and intensity of training loads; ratios of means and loads of different orientation in separate structural formations of training process.

Use of modeling methods at the forming stage of experiment has allowed to develop models of structural formations programs of training process.

Development of structural formations programs of training process of the skilled football players was based on the system conceptual approach and was carried out according to the scheme: the choice of model of an annual macrocycle (special planning has been chosen) $\square$ development of the program of each of preparation cycles $\square$ development of the training program of (competitive) microcycles $\square$ development of programs of separate 
trainings. Such approach to creation of training process has allowed to plan optimum training influences by application of loads of different orientation, different means of training and different types of training of the skilled football players.

The program of a separate macrocycle of the skilled football players consisted of four blocks. In these blocks presented: terms of carrying out periods or stages of preparation; general parameters of trainings (training days, training occupations, games); ratio of training means and loads of different orientation; criteria of players preparedness [13].

Control of players' physical preparedness indicators was executed at the all stages of a pedagogical experiment. Control provided tests which meet the requirements of reliability and informational content and are applied in practice of skilled football players training [6, 12, 18]: $30 \mathrm{~m}$ run, shuttle run $7 \times 50 \mathrm{~m}$, long jump from the spot, Cooper's test. Testing was carried out according to the standard technique in the main part of training after obliging warm-up. Athletes were previously provided instructions concerning correctness of test performance.

For $30 \mathrm{~m}$ run was considered the best result of the player from two attempts (rest between attempts was 3-5 minutes). Shuttle run $7 \times 50 \mathrm{~m}$ provided passing by football player $50 \mathrm{~m}$ distances with obliging condition that the supporting leg put over the line of start and finish. Three attempts were provided for the athlete to perform a long jump from the spot and the best result was fixed. Cooper's test for evaluation of the general endurance of football players provided continuous run during 12 minutes with definition of distance which was passed by the player (firstly 15 minute warm-up was carried out, then was 5 minutes rest and after that the test was carried out).

Statistical analysis. The descriptive statistics was used during processing results of research. It were defined indicators which characterize selection of objects (an arithmetic average, an average square deviation), Shapiro-Wilkie criterion of coherence, Student's t-test parametrical criterion. The difference between indicators was considered reliable on significance value $p<0,050$. Processing of results of research was carried out with the help of software Excel, Statistica 10.0.

\section{Results.}

The program of the second cycle within annual training of the skilled football players at the forming stage of experiment (123 days) is presented in fig. 1 .

The programs of training microcycles were developed on the basis of the second cycle program of skilled football players training (tabl.1) In each program of training microcycles were considered the following components of trainings: value and orientation of loads; means (nonspecific and specific); modes of coordination complexity of exercises' performance; training time; time for renewal of competition form, theoretical and psychological preparation; load coefficient value; intensity of training load coefficient.
Each program of training microcycle consisted in loads of different orientation and volume and intensity of trainings (fig. 2).

In general for the 2nd cycle of annual training of the skilled football players training influences were stipulated by application of glycolytic loads: $55,7 \%$ of aerobic, $37,9 \%$ of mixed, $3,5 \%$ of anaerobic alactic and $4,5 \%$ of anaerobic.

The biggest volume of the general physical training means (GPT) was observed at the preparatory period $(56,3 \%)$ and at the intermediate stage $(100,0 \%)$. Means of the special physical training (SPT) were mostly used at the preparatory period $(17,8 \%)$. At the competitive period the biggest part was means of technical and tactical (TTP) $(28,6 \%)$ and game (GP) $(19,7 \%)$ preparation. Content of training influences on the preparatory of players during the 2nd cycle of annual preparation has been stipulated by means: GPT - for 49,2\%; SPT - for $8,5 \%$; TTP - for $25,1 \%$; GP - for $17,3 \%$.

The analysis of control tests' results at forming stage of experiment has confirmed efficiency of programming of skilled football players training process.

In comparison with statement stage of experiment were positive changes in speed and strength qualities' indicators at the preparatory and competitive periods; special and general endurance. At the preparatory period indicators of $30 \mathrm{~m}$ run have increased by $2,1 \%(\mathrm{p}<0,050)$, a long jump from the spot - by $2,8 \%(\mathrm{p}<0,050)$, shuttle run $7 \times 50 \mathrm{~m}$ - by $3,2 \%(\mathrm{p}<0,050)$, Cooper's test - by $4,8 \%$ $(\mathrm{p}<0,050)$. Positive dynamics in results of football players preparedness was observed also during the competitive period. Decrease in indicators of preparedness at intermediate stage is connected with considerable reduction of loads volumes.

\section{Discussion.}

The analysis and comparison of the obtained data allows to state exclusive practical value of use of the offered systemical and conceptual approach to the development of programs of training of football players. It is connected with the fact that researches concerning problems of realization in practice of reasonable theoretic and methodical provisions of programming of football players training are limited [17]. In comparison with model and target approach $[11,12]$ the programming allows to plan optimum training influences. Programming is carried out by a variation of load components and training means at the different stages of annual and longterm training of football players.

Current trends of team game sports' development stipulated the necessity of application of integrated scientifically-based approach [7, 9, 12]. The offered technique of programming of the skilled football players training is the perspective direction of training process' optimization: programs of trainings, micro and mesocycles, stages and periods of annual macrocycle weren't limited by selective influence on the separate sides of preparation. The received results were compared with other researches $[25,29,32,33]$. The offered program 


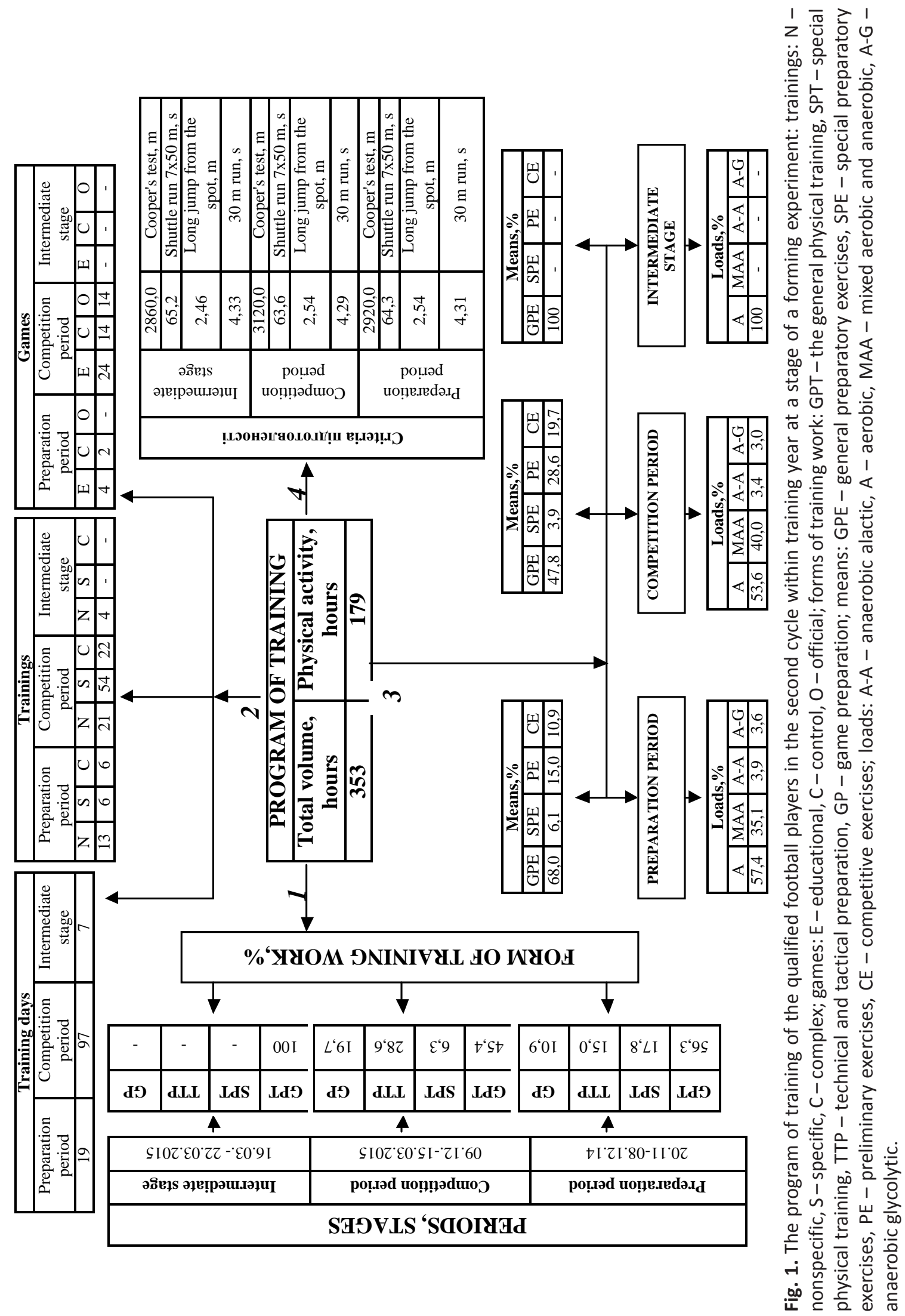


Table 1. The fragment of 6-day preliminary microcycle program of the 2 nd cycle of annual training of football players at the stage of forming experiment

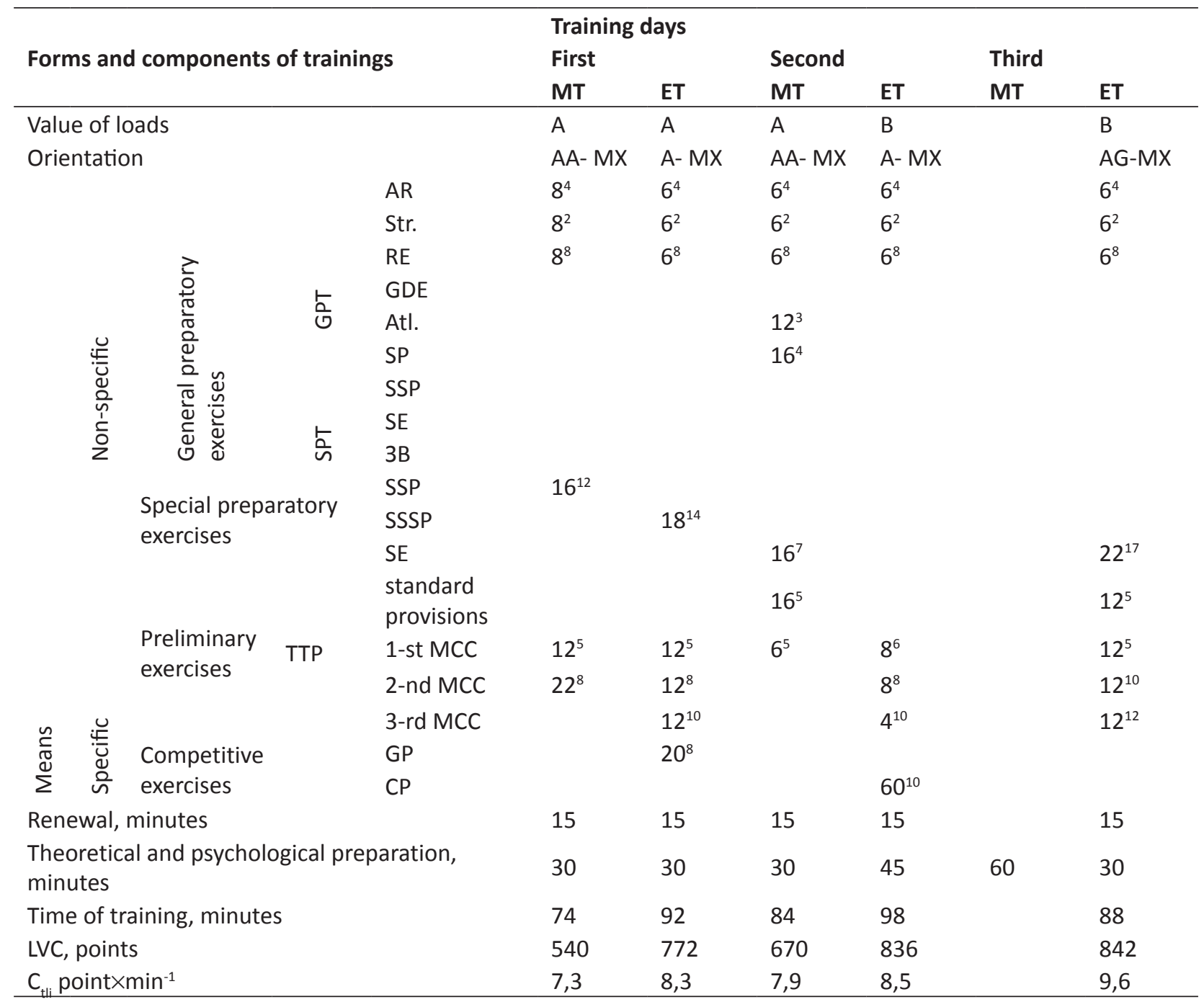

Notes: MT - morning training; ET - evening training; loads value: A - average, B - big; orientation of load: AA anaerobic alactic, A - aerobic, $M X$ - is mixed aerobic anaerobic, AG - anaerobic glycolytic; means: GPT - general physical training, SPT - special physical training, TTP - technical and tactical preparation; LVC - load value coefficient; $\mathrm{C}_{\mathrm{tli}}$ - coefficient of training load intensity; AR - aerobic run; Str. - stretching; RE - running exercises; GDE - general developing exercises; Atl. - athleticism; SP - speed preparation; SSP - speed and strength preparation; SE - speed of endurance; SSP - special speed preparation; SSSP - special speed and strength preparation; SE - special endurance; MCC - mode of coordination complexity; GP - game preparation; CP - competitive preparation; record like " 8 " where, 8 - time of exercise in min., 4 - intensity of exercise in points according to V.M. Sorvanov (1978).

consisted of generally prepared, specially prepared, preliminary, competitive means and loads of different orientation. They were used for improvement of the general and special physical, technical, tactical and game preparation of football players. Such means and loads which are rationally connected to the means of physical efficiency renewal of players: control system; means of theoretical and psychological preparation. Integrated scientifically-based approach at creation of microcycles programs at the forming stage experiment provided such basic provisions and regularities as $[4,6,8,16]$ :

- each microcycle (except the renewal) has to consist of two phases - stimulation (connected with performance of determined volume and orientation of load) and renewal;
- within separate microcycles there is an interaction of the set aside training effects of each previous occupation with urgent training effect of the next occupations;

- changing of occupations in a training microcycle has to consider a renewal heterochronia of different functions. Changing of occupations in a training microcycle has to be carried out in the following way: loads are planned by time intervals sufficient for achievement of supercompensation phase of the leading function; load of other training influence shouldn't have negative impact on renewal of dominant function.

Programming of structural formations of training process has allowed to define: volume, intensity and volume of load; ratios of means and loads of different 


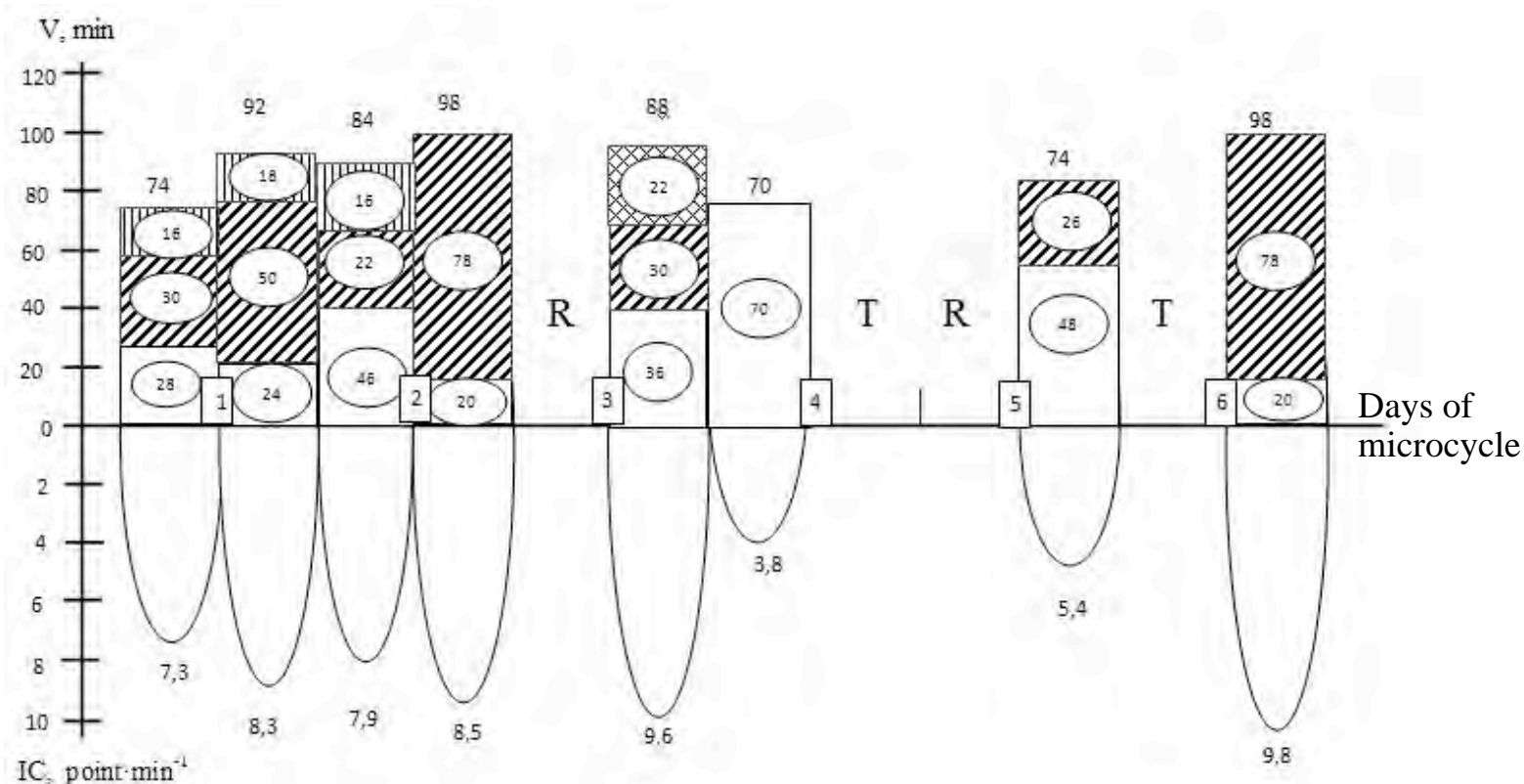

Fig. 2. The volume, intensity and orientation of trainings of 6-day preliminary microcycle of the 2 nd cycle of annual training of the skilled football players at a stage of forming experiment:

$\mathrm{V}$ - volume (min);

$\mathrm{Cl}$ - coefficient of intensity $\left(\right.$ point $\left.\times \mathrm{min}^{-1}\right)$;

$\mathrm{R}$ - rest;

T - theoretical occupation;

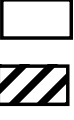

- aerobic loads;

- mixed aerobic and anaerobic loads;

III - anaerobic alactic loads;

$\triangle 8$

- anaerobic glycolytic loads.

orientation in separate trainings, microcycles, stages and periods.

Results of research confirmed phasicity of athletes' competitive form development $[12,16,18]$. The developed system of training process provided development of preparation programs with such condition that each of phases of competitive form correspond to certain stage of training cycle: at the preparatory period were solved tasks of competitive form formation; in competitive - its keeping and the subsequent increase; at a intermediate stage - temporary loss.. Therefore the concept of planning of skilled football players training process provided:

1) increase in volumes of specific means of trainings from microcycle to microcycle during the preparatory period; an optimum ratio of nonspecific and specific means in the competitive period;

2) gradual inclusion to the training process of anaerobic alactic and then anaerobic glycolytic loads (for maintenance of condition of players' competitive form such loads were planned also in the competitive period) against the background of the sufficient volume of aerobic loads.

The analysis of dynamics of physical preparedness indicators of the skilled football players at stages of macrocycle displays phases of players' competitive form formation.

The program of the second cycle of annual preparation has been developed for the purpose of effective preparation and participation in competitions of futsal. These competitions were mainly carried out in winter months. The structure and content of training process provided features of players' competitive activity in a futsal. On the other hand it was provided that loads on the volume and intensity had to be easier from the first and third cycles of annual preparation. The second cycle of preparation had supporting character. First of all it has been caused by features of competitions calendar of the college football teams on the basis of which shorter intermediate stages of the first and second cycle of annual preparation have been planned. The received results were compared with researches of V.M. Shamardin [18]. At the preparation period of the second macrocycle it is found big loads of aerobic orientation and smaller loads of anaerobic. The received results confirm the previous researches $[11,12$, 28] concerning ratio of training's means of the skilled football players in the periods of the second macrocycle.

The optimum ratio of training work means and 
loads of different orientation allows to optimize process of training of the skilled football players. The received results of a research have confirmed a hypothesis: creation of training process of the college football teams on the basis of programming is effective.

\section{Conclusions}

1. The research of optimum ways of creation of training process of training of athletes is important at the present stage. Programming is one of structural formations of the training process.

2. Programming of athletes' training process has to be carried out on the basis of systemical and structural approach: development of programs of less structural formations has to be subordinated to main structural formations. Thus, programs of training occupations formatiions included into structure of microcycles. Programs of stages consist of series of training microcycles programs. The program of a training cycle unites all structural formations.

3. Programming allows to determine accurately the volume and orientation of training influences (both in the course of the separate training occupations, and within microcycles, stages of an annual macrocycle), purposefully to form training effects. The programs of structural formations of skilled football players training process were developed and experimentally proved in the course of the research.

4. The subsequent researches of scientific problem will be directed to programming of training process of football players of different qualification.

Special moments. Programming of training process is one of perspective methodical approaches in the course of athletes' training. Programming has differences from planning of training process. Programming allows to form training effects purposefully: urgent, set aside, cumulative. First of all it is caused by programs of trainings and training microcycles. The main structural unit of training programs is model training tasks. Such tasks aren't considered in this article.

\section{Acknowledgements}

The study has been fulfilled within "The summary plan of scientific and research work of Ministry of Science, Youth and Sport of Ukraine during 2011-2015 pp." by topic "Theoretical and methodical bases of Individualization in physical training and sport" (state registration number is $0112 \mathrm{U} 002001$ ).

\section{Conflict of interest.}

The authors state that there is no conflict of interest.

\section{References}

1. Bukuev MA. Technique of the step-by-step programming of training loads of highly skilled players in the annual cycle. Dokt. Diss. Moscow; 2001. (in Russian)

2. Verkhoshanskij IuV. Programming and organization of the training process. Moscow: Physical Culture and Sport; 1985. (in Russian)

3. Vozniuk TV. Optimization of the training process of qualified basketball players by means of speed-force orientation at the pre-competitive stage of preparation.Cand. Diss. Lviv; 2006. (in Ukrainian)

4. Volkov NI, Nesen EN, Osipenko AA, Korsun SN. Biochemistry of muscular activity. Kiev: Olympic Literature; 2000. (in Russian)

5. Vrublevskij EP. Teoretical and methodological substantiation of programming of a macrocycle of preparation of the athletes specializing in speed-force kinds of track and field athletics. Slobozhans'kij naukovo-sportivnij visnik, 2011;4:74-77. (in Russian)

6. Godik MA. Physical training of football players. Moscow: Terra-Sport, Olympia Press; 2006. (in Russian)

7. Doroshenko EIu. Management of technical and tactical activities in team sports games. Zaporozhye: LLC «Lins» LTD; 2013. (in Russian)

8. Issurin VB. Block periodization of sports training. Moscow: Soviet Sport; 2010. (in Russian)

9. Kozina $\mathrm{ZhL}$. Individualization of training athletes in game sports. Kharkov; 2009. (in Russian)

10.Kostiukevych VM. Theoretical and methodological aspects of programming of the training process of athletes. Aktual'ni problemi fizichnogo vikhovannia ta metodi sportivnogo trenuvannia, 2016;1: 138-142. (in Ukrainian)

11.Kostiukevych V. Modeling in the system of training highly qualified athletes. Fizichna kul'tura, sport ta zdorov'ia nacii,

\section{4;18(2):92-102. (in Ukrainian)}

12.Kostiukevych VM. Theoretical and methodological bases of simulation of the training process of athletes of playing kinds of sports. Dokt. Diss. Kiev; 2012. (in Ukrainian)

13.Kostiukevych V, Stasiuk V. Programming of the training process of skilled football players in the annual macro cycles. Fizichna kul'tura, sport ta zdorov'ia nacii, 2016;1(20): 323331. (in Ukrainian)

14.Malinovskij SV. Programmed training and sports. Moscow: Physical Culture and Sport; 1976. (in Russian)

15.Mitova $\mathrm{O}$. The concept of the formation of a control system in the process of long-term improvement in team sports games. Fizichna kul'tura, sport ta zdorov'ia nacii, 2016;1(20):353360. (in Ukrainian)

16.Platonov VN. Periodization of sports training. Kiev: Olympic Literature; 2013. (in Russian)

17.Tiulen'kov SIu. Teoretical and methodological approaches to the system of management of the training of football players of high qualification. Moscow: Physical Culture and Sport; 2007. (in Russian)

18.Shamardin VM. Technology of management of the system of long-term preparation of football teams of high qualification. Dokt. Diss. Lviv; 2013. (in Ukrainian)

19.Shinkaruk OA. The concept of forming a system of training, selection of athletes and their improvement. Pedagogics, psychology, medical-biological problems of physical training and sports, 2012;12:144-148.

20.Shchepotina NYu. Construction of microcycles for the training of qualified volleyball players on the basis of model training tasks. Naukovo-pedagogichni problemi fizichnoi kul'turi, 2016;1(70):239-243. (in Russian)

21.Bangsbo J. Fitness training in Football. Copengagen: University of Copengagen; 1994.

22.Bompa TO. Total training for coaching team sport. Toronto: 
Sport books publisher; 2006.

23.Haff GG, Haff EE. Training Integration and Periodization. In: Jay Hoffman editors. NSCA's Guide to Program Design. Champaign: Human Kinetics; 2012.

24.Iohnson IA, Haskvitr EM, Brehm B/ editors. Applied sports medicine for coaches. Baltimore: Wolters Kluwer; 2009.

25.Karsten B, Larumbe-Zabala E, Kandemir G, Hazir T, Klose A, Naclerio F. The Effects of a 6-Week Strength Training on Critical Velocity, Anaerobic Running Distance, 30-M Sprint and Yo-Yo Intermittent Running Test Performances in Male Soccer Players. International journal of sports physiology and performance. 2016;11(1):80-85. doi:10.1371/journal. pone. 0151448

26.Kormelink H, Seeverens T. Developing Soccer Players. The Dutch Way; 1997.

27.Kormelink H, Seeverens T. The Dutch Coaching Notebook: The Ultimate Companion For All Ages; Versand: onLi Verlag; 1997.

28.Kostyukevich VM. The construction of the training process highly skilled athletes in soccer and field hockey in the annual cycle of training. Pedagogics, psychology, medicalbiological problems of physical training and sports, 2013; 17(8): 51-55. doi:10.6084/m9.figshare. 750446
29.Mathavan SB. Short Term Training Programme's Impact on the Variables of Dribbling and Kicking performance among University Men Soccer Players. International Journal of Sports and Physical Education. 2015;1(1):23-28.

30.Michels R. Teambuilding, The Road to Success. Spring City: Cardinal Publishing Group; 2001.

31.Morgans R, Orme P, Anderson L, Drust B. Principles and practices of training for soccer. Journal of Sport and Health Science. 2014;3(4):251-7. doi:10.1016/j.jshs.2014.07.002

32.Shalfawi S. Anaerobic conditioning of soccer players: the evaluation of different anaerobic training methods on soccer player's physical performance. Doctoral thesis; 2015.

33.Süel E. The Effect of Skill-Based Maximal Intensity Training on Power, Agility and Speed (PAS) in Female Team Sport Players. Anthropologist. 2015;21(1-2):120-8.

34.Turner AN, Stewart RF. Strength and Conditioning for Soccer Players. Strength and conditioning journal. 2014;36(4):1-13.

35.Wilmore IH, Costill DL, Kenney LW. Physiology of sport and exercise. Illinois: Human Kinetics; 2012.

36.Zouhal H, LeMoal E, Wong DP, BenOunis O, Castagna C, Duluc C, Owen AL, Drust B. Physiological Responses of General vs. Specific Aerobic Endurance Exercises in Soccer. Asian Journal of Sports Medicine. 2013;4(3):213-20.

\section{Information about the authors:}

Kostiukevich V.M.; http://orcid.org/0000-0002-9716-134X; kostykevich.vik@gmail.com; Vinnytsya State Pedagogical University Named After Mikhaylo Kotsubinskiy; Ostrozhskiy str. 32, Vinnytsia, 21100, Ukraine.

Stasiuk V.A.; http://orcid.org/0000-0002-7512-5794; stasyukva@ukr.net; Kamianets-Podilskyi Ivan Ohienko National University; Ohienko str. 61, Kamianets-Podilskyi, Khmelnytsky reg, 32301, Ukraine.

Shchepotina N.Yu.; http://orcid.org/0000-0002-9507-3944; shchepa@mbox.vn.ua; Vinnytsya State Pedagogical University Named After Mikhaylo Kotsubinskiy; Ostrozhskiy str. 32, Vinnytsia, 21100, Ukraine.

Dyachenko A.A.; http://orcid.org/0000-0002-5131-5665; kdyachenkoanna85@gmail.com; Vinnytsya State Pedagogical University Named After Mikhaylo Kotsubinskiy; Ostrozhskiy str. 32, Vinnytsia, 21100, Ukraine.

Cite this article as: Kostiukevich VM, Stasiuk VA, Shchepotina NYu, Dyachenko AA. Programming of skilled football players training process in the second cycle of specially created training during the year. Physical education of students, 2017;21(6):262269. doi:10.15561/20755279.2017.0602

The electronic version of this article is the complete one and can be found online at: http://www.sportedu.org.ua/index.php/PES/issue/archive

This is an Open Access article distributed under the terms of the Creative Commons Attribution License, which permits unrestricted use, distribution, and reproduction in any medium, provided the original work is properly cited (http://creativecommons.org/licenses/by/4.0/deed.en).

Received: 19.06.2017

Accepted: 26.07.2017; Published: 08.12.2017 